\title{
CATEGORY OF "PROPERTY" AND SUBJECTS OF PROPERTY RIGHTS PROTECTION OF THE ECHR
}

\section{Kizlova O. S.}

\section{Introduction}

The questions of the subjective structure of the procedure for protecting property rights in the ECHR has been controversial for a long time among researchers and lawyers due to the perception that prevailed for quite a long period that commercial organizations cannot be applicants to the European Court of Human Rights (hereinafter referred to as the ECHR). To a certain extent, it was based on the title of the European Convention for the Protection of Human Rights and Fundamental Freedoms (hereinafter referred to as the Convention), which contains an indication of human rights and freedoms; partly - of the wrong interpretation of the provisions of Art. 34 of the Convention, which provides the possibility of applying to the ECHR for individuals, non-governmental organizations or groups of individuals. This misconception about the ability of the ECHR to deal with complaints of commercial organizations also led to the fact that its case practice was not analyzed for the purpose of its use in resolving commercial disputes and therefore did not have the effect that it would, in fact, have on law enforcement (including judicial) practice. This highly pervasive misconception was to some extent "undermined" by the ECHR's ruling on the individual complaint of the Russian joint-stock company "Sovtransavto contra Ukraine" (ECHR judgment of October, 2nd 2003 in the case of "Sovtransavto Holding contrat Ukraine", № 48553 complaint / 99 (CASE of Sovtransavto HOLDING art. UKRAINE). The case is based on the application (№ 48553/99) filled in court against Ukraine by the Russian company 'Sovtransavto-Holding' on May 11th, 1999 in accordance with the Article 34 of the Convention for the Protection of Human Rights and Fundamental Freedoms.

Most other human rights and fundamental freedoms can only be used by private individuals otherwise the articles which regulate these rights and freedoms can be interpreted as not extending to legal persons ${ }^{1}$. At the same time, the European Court of Human Rights also gave more signification to the term "person" according to Convention and allows supporting claims of

\footnotetext{
${ }^{1}$ Гомьен Д. Европейская конвенция о правах человека и Европейская социальная хартия: право и практика / Гомьен Д., Харрис Д., Зваак Л. М., 1998. 598 с.
} 
churches as non-governmental organizations, which are not commercial entities under Art. 1 of Protocol № 1

\section{Substantive composition of the applicants to the ECHR}

Unlike most provisions of the Convention, Art. 1 of Protocol № 1 protects the rights not only of individuals but also of legal entities such as companies. This aspect of this article is important because the economic system of the Member States of the Convention is based on the right of private ownership and the right to freely create such economic units as "legal entities": non-governmental organizations, religious bodies, mass media, etc.

The fundamental principle that defines the subjective side of property law is the principle of equality - all persons have equal legal rights, no one can be discriminated against on the basis of sex, race, color, language, religion, political or other beliefs, national or social origin, belonging to national minorities, property, birth or other circumstances (Article 14 of the Convention) (The judgment of the European Court of Human Rights in the case of Pine Valley Development Ltd and others vs Ireland, November 29,199; The judgment of the European Court of Human Rights in the case of Chassagun and others vs France April 29, 1999). According to this principle, private-law entities have the same rights regarding their property and are subjects to the same property rights regime as individuals.

Also, legal entities have the right to complain to the ECHR, which were eliminated in the bankruptcy process (the judgement in the case "Terem v. Ukraine"), and the sole owners of a certain company.

In order to benefit from the protection of article 1 of the First Protocol, a person must have at least some right under national law that could be considered a property law under the Convention. (Monica Karss-Frisk. The right to property: implementation of article 1 of the First Protocol to the European Convention on human rights) ${ }^{2}$.

As the researchers of the ECHR practice established, the applicant's position should be related to the concept of "victim". That is, unlike some articles of the European Convention, only a real victim, not a potential one, can be protected in the ECHR, in accordance with article 1 of Protocol № 1, in the context of violation of property rights. For a person to be recognized as a" victim", it is necessaryto undergo specific intervention by a public authority. Demonstrative case is "Klass and others V. Germany", according to which the European court pointed out: "To each individual applicant to be

\footnotetext{
${ }^{2}$ Свропейська конвенція 3 прав людини: основні положення, практика застосування, український контекст. /За ред. О. Л. Жуковської. К.: ЗАТ “ВІПОЛ”, 2004. С. 685-722. C. 60 .
} 
actually a victim of violations, which he claims about, he can apply to the ECHR. The European Convention does not grant individuals the right of actio popularis (appeal to the European Court of justice in the interests of the people), does not allow to file a complaint against the law in abstracto just because it violates the Convention. It is not enough for an individual applicant to argue that the very existence of the law violates his right under the Convention. It is necessary that the law was applied with causing appropriate damage tothe applicant"3.

Also, as O. Shupinska belives, the issue of the possibility of persons of public law to be covered by the scope of article 1 of Protocol № 1 is controversial, since the state according to the same rules is primarily as an obligated entity, and all private persons who have the right to demand from the state to respect their property rights are called Owners. If to extend the scope of article 1 of Protocol № 1 to public owners, there is a danger that the ownes and the obligated person with regard to a particular property coincide in the person of one entity. And from the point of view of the theory of subjective rights the owner must necessarily confront the duty-bearers ${ }^{4}$.

The practice of the ECHR has established that state organizations, state enterprises or persons financed from the state budget cannot be applicants to the European court of human rights. This thesis is confirmed by the practice of the European court of justice, which considered disputes involving persons of public law. But, applicants can be state persons (the case "the Former king of Greece and others against Greece").

Regarding the responsibility of the State and the entities whose actions it bears this responsibility for, lawyers note the following:

- actions of the state bodies and their subordinates;

- actions of non-governmental companies, if they are owned by the state or controlled by it; financially and operationally independent of the state, but fulfil socially significant functions (decision in the case "Evaldssonandother V. Sweden").

- actions of municipal enterprises and institutions-schools, kinder gardens, medical establishments;

- actions of local governments.

In order to benefit from the protection of article 1 of the First Protocol, a person must have at least some right under national law that could be considered as a property right under the Convention. This point is demonstrated by the Court hearing of many applications.

3 Що таке право власності та як його захистити в ЄCПЛ// URL: http:// yur-gazeta.com/publications/events/shcho-take-pravo-vlasnosti-ta-yak-yogo-zahistiti-v-espl.html

${ }_{4}^{4}$ Шупінська О. Міжнародні правові механізми захисту права власності: практика Європейського суду з прав людини / Олена Шупінська. // Юстініан. 2008. № 11. 


\section{The concept of property rights in the attitude of the ECHR}

The concept of property rights in the attitude of the ECHR is characterized by the "value" concept of property rights. The value concept of property rights is based on the provisions of the basic European standards and it is characterized by: equality of subjects of private property, the extension of property rights to objects that are characterized by signs of economic value regardless of their tangible or intangible nature, besides the list of such objects is not exhaustive and constantly expands with the development of economic relations, the imposition of obligations to ensure and protect property rights to the state, broad powers of the owner, etc. In addition, there may be differentiated regimes of absolute property law for different objects, as well as the existence of absolute property law in respect of rights arising from the enforceable relationships. The content of the property law is characterized by the ability of the subject at its discretion to perform any actions that are not prohibited against the object of the property law.

The provisions of EU law regarding property law, the provisions of property law in EU States and the provisions of legislation with regard to the property law in non- EU member States of the Council of Europe are not unified, since the $\mathrm{EU}$ is currently in the process of harmonizing property law and the process of creating an acquis communautaire in the sphere of property law (in particular, ideas are being put forward for the preparation of the draft European Civil code, but they relate to the draft acts of EU legislation as early as 2010 and are at the initial stage of development and discussion.

Taking into account the practice of the European court of human rights, scientists argue ${ }^{5}$, that the category of property law in the Convention for the protection of human rights and fundamental freedoms has an Autonomous meaning and may not coincide with what is accepted in national legal systems.

This opinion is held by Russian legal scholars V. V. Starzhenetsky and I. V. Mingazova and explained by the fact that the application and interpretation of international treaties corresponds to international legal rules, and legal constructions adopted in national legal systems cannot have a determining value for international legal regulation ${ }^{6}$. That means there is a special concept of the of property law which is independent from the domestic interpretation at the international level. The Convention is an international Treaty, therefore, the process of interpretation and application of its provisions is subject to international legal rules.

${ }^{5}$ Шупінська О. Міжнародні правові механізми захисту права власності: практика Європейського суду з прав людини / Олена Шупінська. // Юстініан. 2008. № 11.

${ }^{6}$ Старженецкий В. В. Соотношение международного (европейского) и российского правового регулирования института собственности. М., 2003. С. 88; Мингазова И. В. Право собственности в международном праве/ И. В. Мингазова. М.: Волтерс Клувер, 2007. C. 5. 
The Institute of the Protection of Property Rights received a special growthin the decisions of the European Court of Human Rights, which can be defined as a departure from the substantive concept of property law that is common for Ukrainian property law. To qualify a particular object of legal relationship as "property", the first and main sign is "economic value". As to interpretation of European judges, the Institute for the Protection of Property Rights must extend to all current assets thatare characterized by economic value, regardless of their tangibility or intangibility ${ }^{7}$.

The other feature is the sign of reality, since property must exist in the real world. The experience of the European Court of Human Rights shows that Art. 1 of Protocol № 1 is applied only to real property, not to the right to acquire property. The case of Malous v. Czech Republic is significant, where the European Court of Human Rights disagreed with the applicant that he owned the property expropriated by the applicant's father under the 1948 national law. The European Court of Human Rights stated that, in the course of the domestic proceedings, neither the father nor the applicant, as his heir, owned the expropriated property. Therefore, in this case it is impossible to talk about "existing" or available property. (the judgment in the case of Malous v. Czech Republic of December 13th, 2000).

There is a dispute about the definition of the object of protection which is defined in Article 1 of Protocol № 1 in the scientific community. For instance, O. Shupinska considers, referring to S. Shevchuk, that the object of protection of the Convention is property rights, according to the content of Art. 1 everyone is guaranteed with the right to respect for his property and certain guarantees of the rights of individuals are provided in case of interference by the state in their rights. The Court directly stated that Article 1 guarantees "ownership": this is a direct consequence of the use of the words "ownership" and "use of property" (in French, "biens", "propriété, "usage des biens"); the preparatory materials also confirm this unequivocally: the developers have repeatedly referred to "property law" or "right to property" to delineate the object of projects that preceded the adoption of Article 1 of Protocol № 1. Indeed, the right to dispose of property is a traditional and fundamental aspect of property law ${ }^{8}$. Some scientists also point out that property law can be positively enshrined in the Convention as a fundamental human right ${ }^{9}$.

\footnotetext{
${ }^{7}$ Старженецкий В. В. Россия и Совет Европы: право собственности. М., 2004. 208 с. C. 50.

${ }^{8}$ Шевчук С. Судовий захист прав людини: Практика Європейського Суду 3 прав людини у контексті західної правової традиції. Вид. 2-е випр., доп. К.: Реферат, 2007. C. $695-701$.

${ }^{9}$ Нешатаева Т. Н. Международное частное право и международный гражданский процесс. М., 2004. 624 с. С. 165-166; Старженецкий В. В. Россия и Совет Европы: право собственности. М., 2004. 208 с. С. 46.
} 
Nevertheless, according to Professor N.S. Kuznetsova, there is nothing about property in the Convention, instead of it the term "possessions" is used in Art. 1 of the First Protocol which is intepreted as property. Michele de Salvia, a professor of law and legal counsel at the EUHR points out that any object that has property values can be a protected ${ }^{10}$.

N.S. Kuznetsova states that without any doubt virtually the only prescription relating to property - the Convention combines all the rights of a natural or legal person with property value. In some places they are called "economic assets". Such a broad approach to the definition of objects is covered by state guarantees within the meaning of Art. 1 of the First Protocol as well as is confirmed by the ECHR practice ${ }^{11}$.

The Convention integrates all the rights of a natural or legal person, which include property value in Art. 1 of the First Protocol, in virtually a single prescription relating to property.

In addition, it should be noted that the European Court's interpretation of property law is not absolute and should be restricted in the name of the general interest of society. Exactly this idea - limiting the absolute right of everyone for the benefit of all - is the cornerstone of conteprorary judicial protection of property. However, restrictions on property rights cannot be arbitrary: in States Members of the Convention property rights can be restricted to the common good in only two forms: control over its fair use (a positive duty of the State) and deprivation of the owner's property with reimbursement (right, but not obligation of the state).

Considering Art. 1 of the First Protocol to the Convention and the mechanism for its application, it is necessary to remember the three provisions which form the content of this article:

(I) The principle of peaceful possession of property;

(II) Deprivation of property;

(III) Control of usage ${ }^{12}$.

Otherwise, Article 1 of Protocol № 1 has three main provisions:

1) Respect of the property rights ("Every natural and legal person has the right to peacefully own his property");

2) impossibility of deprivation of property ("No one may be deprived of his property except in the interests of society and under the conditions provided by law and the general principles of international law");

10 Право власності: європейський досвід та українські реалії: Збірник доповідей і матеріалів Міжнародної конференції (м. Київ, 22-23 жовтня 2015 року). К.: ВАІTЕ, 2015. 324 c. C. $24-34$

${ }^{11}$ Дивись там же

12 Дивись там же 
3) conditions of restriction of property law in the form of control of the state over its usage ("The preceding provisions shall not detract from the right of the state to enforce such laws as it seems necessary to control the usage of property in accordance with the common interest or to secure the payment of taxes or other fees or penalties ").

The principle of the inviolability of property rights in EU law and in EU countries provides an opportunity to interpret more broadly the notion of "the person's property and his estate" beyond the framework of the established concepts of "property", "thing". Nowadays if to proceed from the "economic relations" of property, paying particular attention to the fact that the concept "property" ("property" / "possessions" / "biens", etc.) is considered in EU law more broadly than the classic "triad" of property rights. Firstly, property relations in the EU are governed by aspect of the EU's four fundamental freedoms regarding free economic choice of "goods, persons, services and investment". Secondly, the concept of "property", which is self-contained in the context of the Convention, refers to a fairly broad category of economic-industrial relations (this is confirmed by the experience of the European Court of Human rights).

The content of property law in the general sense is the right of ownership, usage and disposal. The provisions of the Convention do not define the use of the property, but the precedents make it possible to conclude that the owner may be obliged to take certain actions regarding his property, and the rights to use that property may be restricted by the state. The right to dispose of property in accordance with Art.1 of the First Protocol is a traditional and fundamental aspect of property law. This right provides for the possibility of the owner entering into a legal relationship with another person, regardless of the form which these relationships occur in ${ }^{13}$.

The ECHR interprets the concept of "property" much wider and in the context of article 1 of the First Protocol," property "means not only "existing property", but also a number of economic interests (assets) in contrast to the common understanding of the institution of property law which is typical for Ukraine, as well as in general for the States of the continental system of law. In addition to movable and immovable property, there are shares (and not only in terms of their value, but also in terms of the rights to control the enterprise, which they provide to the owner), patents, licenses, professional clientele ("reputation"), financial compensation awarded by a court decision, the right to a retirement, etc. those are in particular under the protection of article 1 of the First Protocol.

${ }^{13}$ Мармазов В. Є. Захист прав та майнових інтересів у Європейському суді 3 прав людини : навчально-практичний посібник/ В. Є. Мармазов, П. В. Пушкар; ред. М. В. Оніщук. К.: Видавничий Дім “Юридична книга”, 2001. 156 с. 
It should also be noted that the position of the ECHR does not differ from the modern concept of property law. The modern stage of development of property law is characterized by the expansion of its subject area. Experience has shown that the most acceptable legal regime for new objects is the regime of ownership, and therefore it will be useful once again to refer to the legal content of the concept of "thing". Part 1art. 177 of the civil code of Ukraine refers to things money and securities. That underlines the fact that the times when "things" were literally understood by a person as surrounding objects have passed. Another evidence of changing views from the classical paradigm can be considered the appearance in the code of such a complex object as the enterprise. Indeed, an enterprise is not a thing but a property complex including among other things exclusive rights, claims and debts (article 191 of the civil code of Ukraine), and yet it is the subject of not only transactions, but also property rights. On the other hand, these examples are rather an exception (so, to include the enterprise in the property turnover a special article was needed) and the basic prejudice remains almost unchanged. Things as an object of property rights can be divisible and indivisible, movable and immovable, complex and simple, etc., but they remain primarily things for which the defining feature is tangibility (article 179 of the civil code of Ukraine).

And here again it is useful to turn back to history. Roman law was aware of the division of things into "tangible "and "intangible", which occurs in the institutions of Gaius (2.12-14). As an example of what is to be understood by a disembodied thing, Gai imposed the right of inheritance, the right of usus fructus, and the law of obligation. "Comparing this sources with the examples which were given by Gai, it is necessary to admit that dividing things into tangible and intangible, Gai means by the last not things in sense of objects of the external world, but the rights".

Since when trying to apply the regime of property to rights, as well as when trying to include rights in the list of objects of civil rights (art. 177 of the civil code of Ukraine), there is a paradox of "right to law", "intangible things «of Roman law, as it seems to us, can hardly serve as an effective tool for regulating intellectual property relations. Another point of view of D.V. Murzin is:"... intangible property appeared in Roman private law because of its unsurpassed logic reaching to primitiveness in its private manifestations; intangible property was rejected by post-Roman civil law through the practicality of Western civilization and its excessive fascination with the philosophy of materialism"14.

\footnotetext{
${ }^{14}$ Мурзин Д. В. Ценные бумаги - бестелесные вещи. Правовые проблемы современной теории ценных бумаг. М., 1998. С. 70.
} 
Article 1 of Protocol № 1 protects the traditional concept of ownership, which includes movable and immovable property (rights in rem), relationships between individuals (rights in personam), public relations, and intellectual property.

The court, in particular, recognized that the guarantees of Art. 1 of Protocol № 1 shall also apply to such specific facilities as:

- amounts awarded by a final and binding court or arbitration decision; (Stran Greek refineries and StratisAndreadis v. Greece, Application N 13427/87. European Court of Human Rights, Judgment of 9 December 1994.);

- right to refund export VAT; (ntersplav v. Ukraine, Application N 803/02. European Court of Human Rights, Judgment of 5 December 2006);

- the right to a refund of excessively paid tax; (Buffalo SRL v. Italy, Application N 38746/97. European Court of Human Rights, Judgment of 3 July 2003).

- licenses to carry out business activities or provide certain services; (Tre TraktorerAktiebolag v. Sweden, Application N 10873/84. European Court of Human Rights, Judgment of 7 July 1989; Capital Bank AD v. Bulgaria, Application N 49429/99. European Court of Human Rights, Judgment of 24 November 2005.);

- clientele and business relations of the company; (Van Marle and others v. Netherlands, Application N 8543/79. European Court of Human Rights, Judgment of 26 June 1986.);

- domain name; (Paeffgen GmbH $(I-I V)$ v. Germany, Applications N 25379/04, 21688/05, 21722/05, 21770/05. European Court of Human Rights, Decision of 18 September 2007.);

- right to shares; (Sovtransavto Holding v. Ukraine, Applications N48553/99. European Court of Human Rights, Judgment of 25 July 2002);

- the right to engage in fishing (Posti and Rahko v. Finland, Applications N 27824/95. European Court of Human Rights, Judgment of 24 September 2002);

- a share in a pension fund (Müller v. Austria, decree admissibility of Application No 6849/72, filed by Christian Muller v. Austria, December 16, 1974);

- property rights, for example, the right to rental charge (rent) for the use of the land acquired on the basis of a will (decree admissibility No 10741/84 S. v. the United Kingdom of 13 December 1984);

- Private property interests recognized under national law (Beyeler v. Italy, Case [GC] of 5 January 2000, application no. 33202/96); 
- movable property, such as a painting (in particular, "Portrait of a Young Peasant" by Van Gogh, was the subject of consideration in Beyeler v. Italy [GC] of 5 January 2000, application No. 33202/96), or the belongings of the person in his residence (Novoseletskiy v. Ukraine, application no. 47148/99, decision of 22 February 2005) etc ${ }^{15}$.

Therefore, if a person has a certain right that is of economic value and is civil in nature, then such a right undoubtedly constitutes "property" in the sense conferred on it by the ECHR. Property covers a) rights in things (rights in rem) and b) rights in claims (rights in personam). And the property also includes those rights to things that come from contracts ${ }^{16}$.

For instance, the Court took into account, in particular, the legal position which led to financial rights and interests and whether they had economic value in cases involving intangible assets (Paeffgen $\mathrm{GmbH}$ against Germany 18.09.2007, 25379/04 21688/05 21722/05 21770/05 (déc.)). In General, as the researchers establish, prima facie taxation directly concerns property issues, since (in a simplified form) according to the results of taxation, the total value of the relevant property of the person is reduced by the amount of the relevant. But of course the position of the mentioned article of the first Protocol was not adopted to get rid the States of the right to receive taxes, as noted in paragraph two of the article.

Thus, the concept of "property" means not only things (in their classical sense), but any other property that has a certain economic value (economic assets). Moreover, this concept also covers objects that, in Russian law, are quite problematic to attribute to property, but which have undisputed economic value.

According to the 1st article of Protocol № 1, the exception to the concept of "property" can be only the objects that, by virtue of the direct prohibition established by national or international law, are withdrawn from economic circulation or those objects that cannot be owned by private persons, although in fact they will have economic value (for example, some weapons, radioactive materials, drugs).This limitation of private property rights is justified on grounds of public interest, so the state has some discretion in determining what may or may not be the subject of private property rights.

15 Фулей Т. І. Застосування практики Європейського суду 3 прав людини при здійсненні правосуддя: Науково-методичний посібник для суддів. 2-ге вид. випр., допов. K., 2015.208 c. C. $128-130$

${ }^{16}$ Карнаух Б. П. Поняття майна в контексті статті 1 Протоколу № 1 до європейської конвенції про захист прав людини $\mathrm{i}$ основоположних свобод// URL: https://docviewer.yandex.ua/?url=http $\% 3 \mathrm{~A} \% 2 \mathrm{~F} \% 2 \mathrm{Fplaw}$. nlu.edu.ua\%2Farticle $\% 2 \mathrm{Fdownload} \%$ 2F59090\%2F62273\&name $=62273 \&$ lang $=u k \& c=58 \mathrm{dbf} 8163814$ 
In addition, the property does not necessarily have to belong to a person on the right of ownership. This may be another legal right (for example, the property may belong to a person on the basis of a lease agreement, as indicated by the Court in the case "Iatridis v. Greece").

The question of property arises only when a person can be eligible for the relevant property, that is, have a right to it. The right itself to property can be considered within the meaning of article 1 of Protocol № 1, if such a right is specific, properly defined in the applications submitted to the European court of human rights.

On the other hand, the provisions of article 1 of Protocol No. 1 do not guarantee any possibility to become the owner of a particular property.

Thus, the right to index citizens 'savings is not guaranteed as such by the 1st article of Protocol № 1 of the Convention. In decisions "Rudzynska v. Poland", "Trajkovski v. the former Yugoslav Republic of Macedonia", "Hajduk and others v. Ukraine", the Court noted that the specified article does not establish for States of a common debt to carry out systematic indexing of savings to correct the harmful effects of inflation and to preserve the purchasing power of the invested funds, and the applicants are not victims of violation by the state under Protocol № 1 of the Convention, since they did not claim for their real property (that is, the funds that were actually put by the applicants in the Bank, regardless of their present real value), a claimed for benefits (Compensation payments) which they were not entitled at the time for, as this was not provided for by the compensation legislation. Consequently, payments from compensation accounts do not fall within the scope of article 1 of Protocol № 1 of the Convention.

The European Court of Human Rights has repeatedly stated in its decisions that there is no ownership of the property until such a person can assert his ownership. "Statement of rights" may mean "possession of property" referred to in Article 1 of Protocol № 1 to the Convention, if there are sufficient grounds for enforcing this right through a court of law.

Thus, the concept of property rights applied by the Court is very broad and is not limited to material things, but also covers the whole range of intangible objects from intellectual property to obligatory claims.

The concept of "property" within the meaning of Article 1 of the first Protocol to the Convention is self-contained. This means, first of all, that the national legislation of the States Parties of the Convention cannot be considered final in ascertaining of its content. In the case of "Yatridis v. Greece" the European Court stated that the concept of property in Article 1 of Protocol № 1 has self-contained content, which is not limited by the 
ownership of material things. Some other property rights and benefits may also be property rights ${ }^{17}$.

According to the lawyers, self-containment of the concept of property is a necessary measure of the part of the European Court of Justice, whereas, on the one hand, it is intended to promote and secure the right to peaceful possession of a person of his property, on the other, it is connected with the application of a broader concept, that the Council of Europe is composed of a large number of States which have their own national legislation. And the purpose of the European Convention is to set minimum standards that would comply with the legislation of any democratic country that is a member of the Council of Europe.

According to O. Belyanevich, self-containment of concepts does not allow to states to formulate in their national legislation such definitions that would violate the balance of private and public interests. The autonomy of concepts must not be seen as a requirement of unification, but only as a requirement to apply unified rules and principles of the interpretation; in other words, it promotes the harmonization of enforcement standards ${ }^{18}$.

ECHR accepts flexibility in interpretation of terms by law enforcement authorities of State Member - the main things: to be reasonable and to meet the objectives of the Convention ${ }^{19}$.

At the same time, the Court may find it appropriate to apply national law. Thus, the concept of "property", according to the practice of the ECHR, provides for awareness - primarily at the national level - with the position of the court on certain issues. This problem is particularly relevant when the Court's approach is more broaden than that of a national legislator.

For example, the recognition of property as "legitimate expectations" does not fit into the traditional outline of civil rights objects under the current Civil Code of Ukraine, as well as the recognition of economic interests under a license to implement a certain type of activity. Enabling acts at the same time can be recognized as "assets" and covered by the concept of "property". Such situations will require to resolve cases taking into account not only national law, but also the ECHR Convention and practice, taking into account the requirements of the Law of Ukraine "On the Enforcement of Judgments and the Practice of the European Court of Human Rights" of February 23, 2006 No. 3477-IV.

17 Фулей T.I. Застосування практики Європейського суду 3 прав людини при здійсненні правосуддя: Науково-методичний посібник для суддів. 2-ге вид. випр., допов. K., 2015. 208 c. C. 130

18 Право власності: європейський досвід та українські реалії: Збірник доповідей і матеріалів Міжнародної конференції (м. Київ, 22-23 жовтня 2015 року). К.: ВАІTЕ, 2015. 324 c. C. $143-156$.

${ }^{19}$ Дивись там же 
According to O. Belyanevich, "smart expectations" of a person can only be considered legitimate (or legal) expectations. In most cases, the concept of "legitimate expectations" is considered as an element of the rule of law and as an element of "juridical certainty", although it is being disputed. At the same time, "legitimate expectations" are also considered as an object of legal protection (security).

The understanding of "legitimate expectations" as an element of legal certainty was embodied in the case-law of the European Court of Justice, which emphasized in Salumi's case that the effect (consequences) of Community law should be clear and foreseeable to those whom it applies to ${ }^{20}$.

As the scientist notes when applying the self-containment concept of "legitimate expectations" it is necessary to consider the following:

1) in the practice of the ECHR, material things and obligations are analysed in terms of the autonomous concept of "property";

2) the national legislation of Ukraine allows to resolve disputes arising in obligations and concerning the protection of the creditor's right by means of the existing legal structures, therefore the application of the concept of "legitimate expectations" will unjustifiably burden and complicate the practice;

3 ) in terms of provision of legal order in the country, the principle enshrined in Part 2 of Art. 19 of the Constitution of Ukraine is prioritized and cannot be opposed by the autonomous concept of "legitimate expectations";

4) in the conditions of unstable legal order, a transfer of autonomous concepts of the ECHR to the domestic platform should be very careful, since the actions of the party may hide lack of integrity ${ }^{21}$.

The practice of the ECHR and international arbitration recognize that the fundamental of reasonable expectation cannot deny the right of States to amend their legislation. According to Part 2 of Art. 328 of the Civil Code of Ukraine the right of ownership is considered legitimate, unless otherwise directly follows from the law or the illegality of the acquisition of ownership is not established by the court. If the court establishes the illegality of the acquisition of ownership, there is no reason to apply the concept of "legitimate expectations" or give it an advantage over the rules of Art. 19 of the Constitution of Ukraine and the Civil Code of Ukraine on the acquisition of property rights.

\footnotetext{
${ }^{20}$ Право власності: європейський досвід та українські реалії: Збірник доповідей і матеріалів Міжнародної конференції (м. Київ, 22-23 жовтня 2015 року). К.: ВАІTЕ, 2015. 324 c. C. $143-156$.

${ }^{21}$ Право власності: європейський досвід та українські реалії: Збірник доповідей і матеріалів Міжнародної конференції (м. Київ, 22-23 жовтня 2015 року). К.: ВАІTЕ, 2015. 324 c. C. $143-156$.
} 
The theory of legal expectations is quite complex and concerns various spheres of private and public laws, - I. Al-Fateeva states. In civil law, this theory or doctrine is promoted quite problematic, although in the 90s there was a reason for it, when the court practice maintained the existence of the rights of the person to the apartment, which should have come by the implementation of the person's right to privatization, but this person died after submitting the relevant documents for privatization, without becoming the owner of the apartment ${ }^{22}$.

In contrast to the "legitimate expectations" of property are not recognized:

(a) «the expectations that property law, which has long since ceased will be renewed";

b) claims, the effect of which ab initio is due to certain circumstances - if such circumstances do not occur.

An interesting example in this issue is the case of Polachek and Polachkova V. the Czech Republic ${ }^{23}$.

It is important to note that a claim cannot be considered a "legitimate expectation" if it is conditional. Thus, article 1 of Protocol № 1 does not guarantee the right to acquire property by inheritance. This approach was applied by the ECHR in the case "marks V. Belgium", where the Court pointed out that article 1 of Protocol №. 1 protects the already existing property of a person and does not guarantee the right to acquire property either by will or in any other way.

In order to prove that the interference with the property right took place, it is necessary to show that the protection guarantees provided for in article 1 of Protocol No. 1 were violated.

As V. Mikhailenko noted ${ }^{24}$, despite the fact that article 1 establishes the possibility of a person to peacefully own their property, it also has a number of restrictions and features, in particular:

- provides for the protection of their property;

- States the right of any person to freely dispose of his property;

- does not guarantee the acquisition of property;

- does not provide for the creation of a new ownership of the property;

\footnotetext{
${ }^{22}$ Право власності: європейський досвід та українські реалії: Збірник доповідей і матеріалів Міжнародної конференції (м. Київ, 22-23 жовтня 2015 року). К.: ВАІTЕ, 2015. 324 c. C. $79-87$.

${ }^{23}$ Polacek and Polackova v. Czech Republic (dec.) [GC], no. 38645/97, § 62, 66, ECHR [Електронний ресурс] // HUDOC. URL: http://hudoc.echr.coe.int/sites/eng/pages/ search.aspx $? \mathrm{i}=001-22564$.

24 Що таке право власності та як його захистити в ЄCПЛ// URL: http:// yur-gazeta.com/publications/events/shcho-take-pravo-vlasnosti-ta-yak-yogo-zahistiti-v-espl.html
} 
- does not guarantee the preservation of the equivalent value and does not oblige the state to maintain the purchasing power of sums of money placed in financial institutions;

- does not grant foreigners who own property in another country the right of permanent residence in the country for the purpose of using their property.

V. Mikhaylenko points out that «when we appeal to the European court, it should be understood that not any violation of property rights will be recognized as a violation, in the case there are always 2 subjects: the applicant and the defendant. The defendant in the ECHR is always the state. And the property right, accordingly, will be protected by the state only when interference with this right at the national level was caused by the state"25.

Thus, in each specific issue, in each case in which a violation of property rights is involved, the Court checks the actions or omissions of the state, taking into account the balance between the needs of the General public need and the preservation of the fundamental rights of the person. First of all, relying on the fact that the concerned person should not bear a disproportionate and exorbitant burden (the decision in the case "Sporrong and Lonroth V. Sweden").

To assess the conduct of the state in the context of compliance with the requirements of article 1 of the First Protocol, the Court must make a full study of the various interests in the case, taking into account that the purpose of the Convention is to protect rights that are "obvious and weighty". Among other things, the existence of a controversial situation is established. At the same time, when the issue of public benefit does arise in the case, the ECHR requires the state authorities to "respond properly, correctly and with great responsibility" (the decision in the case of "Vasilescu V. Romania" and "beiler V. Spain").

\section{SUMMARY}

So, since the ideology of article 1 of the First Protocol is actually reflected in the Constitution and the Civil code of Ukraine, the national courts should take into account legal positions of the ECHR in disputes on protection of property rights, to refer to the conclusions of the ECHR as a direct source of law, and to adopt in its decision the idea of justice and humanity.

25 Що таке право власності та як його захистити в ЄCПЛ// URL: http://yurgazeta.com/publications/events/shcho-take-pravo-vlasnosti-ta-yak-yogo-zahistiti-v-espl.html 


\section{REFERENCES}

1. Гомьен Д. Европейская конвенция о правах человека и Европейская социальная хартия: право и практика / Гомьен Д., Харрис Д., Зваак Л. - М., 1998. - 598 с.

2. Європейська конвенція 3 прав людини: основні положення, практика застосування, український контекст. / За ред. О. Л. Жуковської. - К.: ЗАТ “ВІПОЛ”, 2004. - С. 685-722. - С. 60.

3. Що таке право власності та як його захистити в ССПЛ // Режим доступу : http://yur-gazeta.com/publications/events/shcho-take-pravovlasnosti-ta-yak-yogo-zahistiti-v-espl.html

4. Шупінська О. Міжнародні правові механізми захисту права власності: практика Європейського суду з прав людини / Олена Шупінська. // Юстініан. - 2008. - № 11.

5. Старженецкий В. В. Соотношение международного (европейского) и российского правового регулирования института собственности. - М., 2003. - С. 88.

6. Мингазова И. В. Право собственности в международном праве / И. В. Мингазова. - М.: Волтерс Клувер, 2007. - С. 5.

7. Старженецкий B. В. Россия и Совет Европы: право собственности. - М., 2004. - 208 с. - С. 50.

8. Шевчук С. Судовий захист прав людини: Практика Європейського Суду з прав людини у контексті західної правової традиції. - Вид. 2-е випр., доп. - К.: Реферат, 2007. - С. 695-701.

9. Нешатаева Т. Н. Международное частное право и международный гражданский процесс. - М., 2004. - 624 с. C. $165-166$.

10. Мармазов B. Є. Захист прав та майнових інтересів у Європейському суді з прав людини : навчально-практичний посібник / В. Є. Мармазов, П. В. Пушкар; ред. М. В. Оніщук. - К.: Видавничий Дім "Юридична книга", 2001. - 156 с.

11. Римское частное право: Учебник / Под ред. проф. И. Б. Новицкого и проф. И. С. Перетерского. - М.: Юриспруденция, 2000. -448 c. С. 148.

12. Мурзин Д. В. Ценные бумаги - бестелесные вещи. Правовые проблемы современной теории ценных бумаг. - М., 1998. - С. 70.

13. Фулей T.I. Застосування практики Європейського суду з прав людини при здійсненні правосуддя: Науково-методичний посібник для суддів. - 2-ге вид. випр., допов. - К., 2015. - 208 с. С. 128-130

14. Карнаух Б.П. Поняття майна в контексті статті 1 Протоколу № 1 до європейської конвенції про захист прав людини і основоположних свобод // Режим доступу : https://docviewer.yandex.ua/?url=http\%3 
A\%2F\%2Fplaw.nlu.edu.ua\%2Farticle\%2Fdownload\%2F59090\%2F62273\& name $=62273 \&$ lang $=$ uk $\& c=58 \mathrm{dbf} 8163814$

15. PolacekandPolackovav. Czech Republic (dec.) [GC], no. 38645/97, $\S 62$, 66, ECHR [Електроннийресурс] // HUDOC. - Режим доступу: http://hudoc.echr.coe.int/sites/eng/pages/search.aspx?i=001-22564.

16. Що таке право власності та як його захистити в ЄСПЛ // Режим доступу : http://yur-gazeta.com/publications/events/shcho-take-pravovlasnosti-ta-yak-yogo-zahistiti-v-espl.html

\section{Information about the author:}

Kizlova O. S.,

Doctor of Laws, Professor, Head of the Department of Civil and Business Law and Process, International Humanitarian University 33, Fontanska Road str., Odessa, 65009, Ukraine 